\title{
NATIVISM, UTOPIA, AND DEATH IN THREE CONTEMPORARY BRAZILIAN NOVELS: A COMPARATIVE READING OF QUARUP, MAÍRA, AND A EXPEDIÇÃo MONTAIGNE
}

José Luiz Passos*

\section{Figura and Political Engagement}

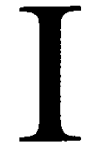

n its seven chapters, and six hundred pages, the novel Quarup (1967) sets a course of prefigured religious and political conversion. With journalistic precision Antonio Callado creates his main protagonist, Fernando (Padre Nando), and parades his dramas of consciousness between theological commitment - devoted to beauty and a certain moral justice - and a certain political commitment that ends up drawing the ex-padre into the Brazilian guerrilla warfare. Fernando seems to represent a meditation upon the motivations for, and possibilities of, action and political engagement. Nando hesitates between history and myth, between reality and utopia, politics and transcendence. The structure of the novel in many ways follows a specific kind of western model of representation

* University of California - USA. 
PASSOS, J. L. Nativism, Utopia, and Death...

and interpretation of symbols, whose essence resides in the medieval concept of figura.

The change of aesthetic sensibility between the ancient pagan and the Medieval Christian world is profoundly related to a shift of perception of the relation between the Old and New Testament. This change coincides historically with the decadence of the Roman Empire and with the Saint Augustine's Synthesis, after which the connection between Moses and Jesus Christ would be understood as a relation of similarity and prefiguration. German critic Erich Auerbach argues that through the concept of figura, Moses and Jesus are understood equally as historical actors and symbolic beings, as events and as signs of what is to come. They are interchangeable symbols, signs of a prefiguration that, according to the critic, characterize a new kind of symbolic representation of the western world.

The figural interpretation - not necessarily figurative - is taken as the development of the prefigured historical being. The figural being - in this case, Moses - anticipates and announces the coming of Christ. According to Auerbach, both are historical and cannot be reduced to allegories or myths. The figural interpretation insists on the historicity of its episodes and agents, which amount to the "law" and to the prefiguration that achieves the profound significance of History as prophecy. Thus, figura has literal significance, historical meaning, and moral truth, which will only be known by the acceptance of the prefiguration, which in turn is only capable of being understood through the act of interpreting the figura.

It is not difficult to perceive the enormous importance that this concept carries out in Western culture from the Middle Ages through to the present day. The figural representation of facts and of symbols is perhaps one of the points of origin of the distinguished position given to the act of interpretation in the Christian cultural tradition, according to which, a group of symbols can relate to other interrelated symbols - revealed through clues ingeniously interwoven in the text and in History - which await deciphering. Furthermore, it is possible to affirm that at various times the method of figural interpretation secularizes through philosophic systems constructed under the concept that those who lived in the past did not understand what they lived; only the future time can fully understand them. This relation between past and future has an end, a direction already predetermined that can be deciphered by an activity of figural interpretation. Figura is found present in the western cultural tradition simultaneously as a mode of representation of reality and a method of its interpretation. In fact, this concept cannot be understood of simply as a mental construct. Instead, it is a malleable structure; figura represents a form of mentality peculiar to the western Christian world. It is a relation that gives meaning and direction to the development of History. (AUERBACH, 1959, p. 11-76).

Returning to Quarup, the presence of the indigenous element in the novel can be understood as a utopian space that functions as the primary motivation for Fernando's actions. His fascination with the lost Guarani Republic, simultaneously 
communist and Christian (CALLADO, 1984, p. 19), is associated with the idea of the myth of the Brazilian geographic center, and the search for the purity of aboriginal Brazil, an undertaking simultaneously mythical and moral. In fact, since the very first pages of the novel the reader is presented with a strong tension between two levels: God and History, or more generally, transcendence and the practical. In the first chapter, Fernando is constantly thwarted in his desire to retreat: in the opening scene of the novel, Levino's blood stains a skull in the seminary's tomb, restoring the lost flesh and the presence of History, "entrando em filetes de distração por todas as frinchas da fortaleza que ele [Nandol fora antigamente" (CALLADO, 1984, p. 12).

The constant presence of two worlds can be seen in the words of Padre André, obsessed with the idea of the Second Coming of Christ: "Escuta, Nando, Escuta. Você não compreende? ficou tanta coisa a ser cumprida, tanta profecia à espera de realização! Houve a Vinda-aviso e ficou faltando a Vinda-preenchimento. Eu juro a você que sinto o Milênio nos ares" (CALLADO, 1984, p. 22). Thus, the Second Coming, in the words of André, can be understood as a type of exaggeration of the idea of redemption that so permeates the theological utopia of the first Fernando and the political utopia of the revolutionary Levindo. Between the two worlds, and between the two characters, is Francisca, "o carreiro das estrelas entre dois mundos" (CALLADO, 1984, p. 12), who guarantees by her beauty the connection between myth and History, and between the past - represented by the tunnel of the "ossuário" and the tiles of Santa Teresa - and the political present, often stained with blood as in the episodes in the Engenho Nossa Senhora do Ó. The first chapter prepares this prefiguration, revealing History as recurrence and fall. The hesitations the narrative attributes to Fernando are equivalent to a preparation for action. Curiously, Fernando's first moral and political convocation is performed by the revolutionary who also sees in the Xingu the utopian space of a redeemed Brazil: "Me ajude, Padre Nando - disse Levindo. - O que eu quero dizer ao Leslie é que precisamos criar dentro do brasileiro a ajuda do Brasil. Temos de fabricar os mitos" (CALLADO, 1984, p. 33).

Francisca, repeatedly associated with the figuras of Dante's Francesca and Beatrice, is described as "a imagem da Doçura anunciando a Tragédia" (CALLADO, 1984, p. 63). She stands for the figural interpretation, which connects the real and the symbolic worlds through beauty and love: "Por trás dos desenhos de Francisca [Nando] enxergava os desígnios de Deus, vivos como um corpo de índia por trás dos arabescos de jenipapo" (CALLADO, 1984, p.77). The presence of the religious themes and of a certain messianic tone in the novel is constant. It reinforces the hypothesis that the main motivation of the work is to contemplate the idea of conversion. The narrative constantly suggests parallels between the two worlds. The rhetorical question of Nando to Lídia - "Você sabia que a religião é a memória da espécie? Nós não esquecemos nada. Carregamos tudo conosco, através dos tempos" (CALLADO, 1984, p. 17) - 
seems to give an explanation of the indigenous rite of Quarup, namesake of the novel and a religious ceremony that celebrates the deity Mavotsinim as well as the ancestors of the tribe. Quarup, as a rite, celebrates the dead.

The presence of Fernando in the Xingu serves two purposes: firstly, the myths about Brazilianess are resurrected, degraded, and demystified. Modernism, Left, Right, nationalism, Bandeirantes, and Sertanistas are defined by the failures of this group that leaves in search of the geographic center of Brazil in a mission of self-discovery. Secondly, Francisca is turned to flesh by her first sexual encounter with the ex-Padre, when "Nando a viu pela primeira vez transferida para $o$ mundo" (CALLADO, 1984, p. 318). In this context, Fernando and Francisca are figuras. Both possess an existence that reveals simultaneously a symbolic and an historic nature. In her parallel with Beatrice, Francisca develops a double existence: daughter of a traditional family and medium of conversion for Fernando, she stands for a moral principle that is capable of orienting the hero's journey of conversion. As "flesh", Francisca revolutionizes and grounds Nando in History, demanding him to take his position. As a symbol of transcendence, she redeems and converts the ex-padre to a revolutionary, guiding a journey of prefiguration that envisions his transformation, not only for political motives but also for moral and aesthetic ones. Fernando ends up encountering a terrestrial object for his compulsion for transcendence in his impulses for beauty, that - as in Horace and Saint Thomas Aquinas - is equivalent to justice.

In one of the episodes of stream of consciousness, which mixes drunken profane intuitions with sublime revelation, Nando experiences the following epiphany:

Francisca ria e não relanceava mais os olhos e Nando se viu chegando e a maçã lhe sendo ofertada mas logo após estava pacificando txikão e txikão disparou a flecha mas ele não se incomodou e a flecha entrou no peito e bateu em alguma coisa dura e clara feita talvez com ossos do ossuário. Nando compreendeu então que a flechada era verdadeira mas que ao mesmo tempo o epesódio todo era para ilustrar a conversa de Francisca cujo tema era a diferença entre um mártir e um mágico. ${ }^{1}$

In this passage, many of the main motives of the narrative are concentrated, sewn together by the presence of a figural mentality of interpretation. Among these elements are: Francisca's smile (the redeeming beauty); the offer of the apple (a parody

1 (CALLADO, 1984, p. 330) 
at the same time of Adam and Eve, and of first contact with the natives); the pacification of the Txikão tribe (a western mission of the redeeming conversion); and the heart/bone of the ossuário (center, origin, and collapse of the separation between the two worlds). Added to all these motifs is the interpretation that Nando's conscience intuits: the arrow wound was at the same time truth and illustration, History and the symbol that prefigures it, which is able of giving meaning to the themes presented to the hero-pilgrim by its Beatrice-Francisca through magic and martyrdom.

Three pages later, Nando is now secure in the path that the narrative has prepared for him: "Tudo que me aconteceu foi uma preparação para você [Francisca]. Para eu amar você até o fim do mundo"(CALLADO, 1984: 333). Francisca, equivalent to a bridge connecting two worlds, is differentiated from the other characters by her metaphysical depth. Many of the characters of the novel have a certain historical profoundness, but only Francisca has the grave and sublime soul of a figura, "só Francisca ainda transcendia e simbolizava alguma coisa" (CALLADO, 1984: 367). Padre Nando, converted to Fernando-Sertanista, then to Nando-professor-of-love, gets involved, in the end, in the guerrilla war and assumes the nick-name "Levindo," first love of Francisca, killed in his redemptive mission.

Nando himself had already given signs of his disposition for political engagement as a principle valid in and of itself, perhaps for beauty and justice, where beauty is once again equivalent to goodness: "Não tente me reconverter - disse Nando [a Padre Gonçalo] - que você consegue. Eu me converto a tudo que exija fervor. Minha falta de caráter é um excesso de zelo" (CALLADO, 1984, p. 397). And so, at the end of the book, Nando-Levindo transforms Francisca into the entire sensible world, and more specifically in the land that cried out for a redeemer, fusing in Beatrice her properties of transcendent symbol and redeemed flesh:

E naquelas trevas as duas imagens de Francisca se acercaram uma da outra, coincidiram, de novo uma só... [Nando] sentia que vinha vindo a grande visão. Sua deseducação estava completa... E viu: aquele mundo todo com sua cana, suas gentes e seus gados era Francisca molhando os pés na praia e de cabelos ardendo no Sertão... Francisca é apenas o centro de Francisca. ${ }^{2}$

The novel fulfills the prophecies set out during the narrative. The theological commitment transcends the imperatives of personal motivations and converts

2 CALladO, 1984, p. 599-600. 
Fernando into Levindo for a teleological journey of death and resurrection. After this political and religious conversion, the actions of the two protagonists, enacted during the course of the plot, assume completely their moral and figural implications, that is to say, all of Nando's hesitations, all of Levindo's utopias, the ambiguous definition of Francisca, the course of the hero's apprenticeship and diseducation, his torment and his pleasure, all can be found and fulfilled in the outcome of his political engagement. It is in this sense that Quarup leads towards religious conversion and political engagement; a journey that the concept of figura helps to reveal.

\section{Requiem Mairum: Myth Awaits Death}

Maíra (1976) has an uncommon structure: mixing bureaucratic reports with indigenous myths, letters, and stream of consciousness, the novel plots a course nearly the opposite of Quarup's. In Quarup, the presence of the conscience of an (ex-) padre is characterized by the western drama of free will and salvation. Maira presents the tragic situation of an ex-seminarian Native Brazilian that, upon returning to his tribe, is condemned to drift among the wreckage of his conversion to the Western god and the impossibility of returning to his original totemic community. Darcy Ribeiro presents what some critics consider "o mais amplo painel até agora visto em literatura da condição dos índios no Brasil" (GALVÃO, 1979, p. 388).

Between the two novels, separated by almost ten years, it is possible to perceive how the religious themes of conversion and of decision-making are kept, though in distinct ways. The intricate texture of the composition takes advantage of mythical structures to fragment the narrative voice, making it oscillate between individual characters and collective entities. Fragmentation confirms, at the level of the composition of the text, one of the main motives of the novel: to represent the collision of worldviews between myth and the Christian god. Just as in Quarup, but in a different way, Maira reflects upon the limits and the possibilities of action for a protagonist that agonizes in the dichotomy of his very consciousness. But instead of being a preparation for action - a valid paradigm for Nando in the context of the 1960's - Isaías atones for his sins through a tense and trembling immobility. Expectation is resolved in the impossibility of action. In one of his appeals to God, Isaías begs to be saved from his very self:

Só me resta morrer, buscar a morte com minha vontade Mairum? Não, ela está dentro de mim dizendo que hei de viver, que a vida é o único bem. Meu morrer seria outro gesto no diálogo contágio, 
mais uma afirmação vazia, outra negação débil. Só resta deixarme viver, para ninguém, para nada.

\author{
Rex tremendae megestatis \\ Qui salvandos salvas gratis \\ Salva me fons pietatis
}

... Tenho tudo diante de mim, permitido. Posso tomar qualquer rumo. Nisso está meu risco. Tenho o arbítrio de mim mesmo, tenho a liberdade de tomar qualquer caminho. O que não tenho, meu Pai, é meta, é alvo. Alvo que seja meu ou que seja Teu, mas alvo a que me possa dar, inteiro. Estou no meio de encruzilhada. É a partir de mim que os caminho se abrem. Qual o meu caminho? $?^{3}$

Isaias is not capable of overcoming the collision of the two conflicting ethical systems: one that takes an ascetic ideal of life and redemption from the expectation of death; and the other, that revolves around the vigorous celebration of life itself. Condemned to "choose" his way in the world, but overwhelmed with guilt and penitence, Isaías ecstatically enacts his own requiem, celebrating his own death, the death of God, and the death of the Mairum community. Curiously, death is denied to the protagonist. All the other characters that in some way embody mixture (for example Juca and Alma) die before the end of the narrative. Not Isaías, he is condemned to remain alive and to have no goal.

One of the critics of this novel affirmed correctly that "questo romanzo è strutturato come una messa per la morte di Dio" (BENSO, 1981, p. 99). In fact, its structure follows this requiem for Isaías, who remains alive watching the collision and death of the two worlds that divide his consciousness. The novel can thus be understood as the death of God in the sense that the mixture of the two worlds causes the dissolution, or the impossibility of the solution, of its protagonist and the hybridity of his own soul, annihilated by the presence of both worlds. The character Alma, who stands for the failed encounter between the two cultures, opens the novel with her death while giving birth to twins, demonstrating the impossibility of reenacting the mythical genesis of the Mairum community. 
In Maira the tension established between "two worlds" is by nature very different from the "worlds" of Quarup, which were two Western worlds, divided between History and God, promise and fulfillment, guilt and redemption. Maíra, in fact, emulates a mythical structure in its attempt to organize symbols that distrust and differ from the Western repertoire. In Quarup the "two worlds" are preserved. The language is preserved. The subject is saved and History in the end finds a martyr. The structure of the novel by Antonio Callado is inherently Western (occidental), in the sense that it maintains the integrity of the Christian model of representing reality: a figural representation that sees in History the justification and the exemplification of itself, as repetition, prefiguration, and fulfillment. In this sense, Quarup mimics History and makes it a figura.

Maira, for its part, imitates myth. Its structure derives from the anthropologic desire to transpose particular modes of organizing symbols with the languages of "historical cultures." The solution that Darcy Ribeiro finds is to show the death of that type of storytelling, transformed in a novel that mimics mythical structures. Once published as a novel, Maíra searches out formal antecedents in past works, like Macunaima, Ulysses, the works of José de Alencar and Guimarães Rosa, and even Quarup. Maira is not a myth; it is a novel that embraces mythic plots. One of the important differences between Maíra and Quarup is precisely the nature of their authors' intentions, that of an anthropologist versus that of a journalist or historian.

Another major difference, still related to the field that these works occupy in literary tradition, is the situation in which the community of writers found themselves at the time in which each of these novels was written. No doubt remains about the fact that in 1967 Quarup's dénouement not only condenses and enacts a large part of the dilemmas faced by Brazilian society at the time, but also anticipates many of the themes and choices embraced by Brazilian intellectuals thereafter. Published in a period in which the hegemony of the intellectual and literary field clearly belonged to the Left, Antonio Callado's novel found an immediate resonance with the social and political environment. Just as Pierre Bourdieu notes about the relation between internal and external aspects of a work within the field of cultural production,

without ever being a direct reflection of them, the internal struggles depend for their outcome on the correspondence they may have with the external struggles between the classes (or between the fractions of the dominant class) and on the reinforcement which one group or another may derive from them, through homology and consequent synchronisms. ${ }^{4}$

4 BOURDIEU, 1993, p. 57. 
Ten years later, with civil society heading towards greater autonomy, with models of anthropological research more consolidated, and with the emergence of more fragmented and polyphonic narratives, Maíra arose almost as the reversion of Quarup's paradigm. Callado's work had taken indigenous symbols only half way, as representation of the desires and utopias of the national intelligentsia in its contemporary attempt to define national identity. Callado's novel demystifies many of these representations of the indigenous Brazilian, parodying various past models, but Maíra would propose the opposite agenda; the model of western representation should be re-mythicized.

The two novels, in spite of their differences, propose a reflection on the possibility of constructing symbols that oscillate between two worlds, orienting the hero's action towards hybrid ethical systems. It is in this sense that Maira and Quarup frequently face religious issues when exploring the sacred substance that guides the personal symbolic repertoires of the their heroes. In relation to Maira,

questo sacro si vede riemergere nella cultura e nella società da cui provengno Isaías e Alma, e - utilizzando un concetto di Bastide - si può definirlo sacro selvaggio. C"è il passaggio dalla comunità mairum, con le sue caratteristiche egualitarie, la sua solidarietà, l'omogeneità delle sue credenze e dei suoi valori, alla società urbana e industrializzata che allenta I legami, scava vuoti, sfocia nella solitudine. ${ }^{5}$

However, there are major differences in the results that the presence of the sacred has in the two novels. In Quarup the method of figural interpretation of History, that guarantees the narrative a structural principle of development, ends up embracing religious and political communion (the revolution is communion, death is redemption, and the martyr is the communed body). Whereas in Maíra, the state of communion is a given and the hero's dissolution is related to the presence of this sacred Western element that undermines the solidarity among the members of the Mairum community. Isaías' solitude is precisely the effect of a division of his soul between two visions of the sacred.

Maíra - the indigenous god, or one of its manifestations - gives commentary on Isaías and his immediate association with the destiny of the indigenous nation: 
Tiraram o seu espírito. Isto que está aí é o que resta de um homem que perdeu a alma. Eu, agora, não tenho mais esperanças, só me resta morrer. Morrer de cansaço de tanto esperar. Morrer de fastio pela vida que me desgostaria viver (...) Nós, os mairuns, estamos acabando. ${ }^{6}$

It is in the soul of the ex-seminarian Native Brazilian that the narrative concentrates the motifs of fragmentation, solitude, and death. When Alma takes control of the narrative, she herself, hybrid in her frustrated desire for total conversion to the Mairum community, comments that "o mal de Isaías é ser ambíguo. Ser e não-ser. Não é índio, nem cristão. Não é homem, nem deixa de ser, coitado. Ser dois é não ser nenhum, ninguém".'

Nevertheless, a similar interpretation is also valid for Alma, who inquires about her place, and that of her possible future children, in the Mairum society. Alma is never sure what she represents and in spite of her sincere desire to be completely converted, the narrative seems to be resolved to say "no" to both Isaías and Alma, opting for the symbolic, or real, death of the two characters. "C'est cette mort qui ouvre le roman, suivie de la mort du vieux chef. Morts encore dans les périls de la forêt, mort intérieure d'Isaías, annonce de la mort future de cette tribu: le thème de la mort baigne tout l'ouvrage".

Thus, if in Quarup the models of western representation of history and of transcendence are intact, guaranteeing the development of the narrative through the belief in a redeeming theology, in Maira the organization of the symbols are found mixed between the indigenous myth and the catholic mass. The development of Darcy Ribeiro's novel, through a hero paralyzed with terror, is projected forward as an endless expectation in relation to death, as a requiem Mairum.

\section{Neither Myth nor History}

Fifteen years later than Quarup and six after Maíra, A Expedição Montaigne, by Antonio Callado, resumes at the beginning of the 1980's the theme of the $\mathrm{Na}$ tive Brazilian through a short novel. Lígia Chiappini M. Leite pointed out that each book by Antonio Callado can be understood as a ramification of Quarup,

6 RIBEIRO, 1978, p. 270.

7 RIBEIRO, 1978, p. 372-373.

8 GONZALEZ, 1982, p. 232-233. 
"profundizando y actualizando, muchas vezes por la negación, una de sus multiples vertientes". In this sense, A Expedição Montaigne can be interpreted as a negative extension of the voyage that Nando, Francisca, and Fontoura, among others, undertake in Quarup in search of the geographic center of Brazil. The second expedition - this time undertaken by Ipavu, a Native Brazilian stricken with tuberculosis, and Vincentino Beirão, an opportunistic journalist - has a "negative" value; negative in the sense that the construction of its characters comes in the form of a satire and an inversion of those from Quarup.

Beirão parodies Levindo and Nando, creating an ironic criticism of the ridiculous visions that the national intelligentsia historically maintained about the idea of Brazilian identity in its association with the image of the indigenous culture. Quarup had already achieved in Nando the parody of both the romantic and the Sertanista's Native Brazilian. A Expedição Montaigne does not even forgive the parodies sketched out by that novel. Everything dissolves in scathing irony, which negates to myth and History any pretense of validity. Nothing survives the expedition. "La dimensión utópica casi desaparece, persistiendo solamente de forma negativa, en la amargura de un mundo vuelto de cabeza hacia abajo; nuestra tragicomedia expuesta". In fact, the negative utopia - the "destopia" - develops itself throughout the novel, reversing the voyage of self-discovery.

Ipavu, prodigal son cast out of the tribe because of his tuberculosis, insists in identifying with the botequim (bar) and with Crenaque - a type of reformatory for delinquent Indians - the space where he projects his desires. Determined to assimilate himself, Ipavu has in the degraded elements of Western culture the equivalent of his personal utopia:

Ipavu não queria por nada deste mundo voltar a ser índio, nu, piroca ao vento, pegando peixe com flecha ou timbó, comendo peixe com milho ou beiju. Queria viver em cidade caraíba, com casas de janela empilhada sobre janela e botequim de parede forrada, do rodapé ao teto, de bramas e antárticas. Índio era burro de morar no mato, beber caxiri azedo, numa cuia, quando podia encher a cara de cerveja e sair correndo na hora de pagar a conta. ${ }^{10}$

Ipavu's desire to "live in a caraiba [western] city" or to transplant its benefits and practices - most notably its beer - to the tribe, has a parallel with the episode in the "Letter to the Icamiabas" in Macunaíma (1928), by Mário de Andrade,

9 LEITE, 1989, p. 492.

10 CAllado, 1982, p. 13. 
which also shows this same fascination with the degraded aspects of the modern metropolis. The same motives that define Mário de Andrade's hero are found present in Ipavu: sterility expressed by a kind of "disorganized pornography"; the compulsion for the easy life and monetary fetishism; ${ }^{12}$ and the perennial sickness that through slow degeneration drives the hero to his death. Between Macunaíma and Ipavu, float the analogous results of characters that embrace with enthusiasm their conversion to Western values. In his letter, Macunaima rehearses his faulty mastery of Portuguese language and culture. Whereas Ipavu, after reprimanding Beirão with a speech full of cunning and slang, feels "a alegria de sentir que já falava tão bem língua de branco que sabia dar uma esculhambação digna de Seu Vivaldo, como se a boca dele, Ipavu, fosse uma sarabatana e as palavras de farpas de taboca que iam se pregando na cara do Beirão".' Thus, civilized with pride, but still hybrid in the way he represents the relation between beliefs and objects, between cause and effect, Ipavu masters the instrument of his "occidentalization" and is capable of realizing his own parodic forays into the world of white culture. Unlike Isaías in Maíra, who suffers and becomes debilitated from the hybridism of his soul, divided between Christian guilt and totemic ritual, Ipavu takes all that suits him and transforms it into an ironic personal repertoire. Note, for example, the way the hero is able to establish comparisons between two of the symbols that characterize own his saga, the church and the bar:

O birosqueiro, que às vezes trepava na escada pra pegar garrafa, parecia até o padre quando sobe a escada daquela varandinha de pau dourado na igreja, pra falar a lenga-lenga dele, história de antepassado, feito pajé, mas o botequim é muito mais bonito e mais sério porque lá não é só o sacana do padre que é servido e que toma o vinho dele, e assim mesmo num dedal dum cálice. ${ }^{14}$

The sacred ritual of Christian mass is understood as the equivalent of the function of the Pajé (the shaman), and both are compared, in caricature, with the service of the botequim, with the clear disadvantage lying with the first two. Ipavu stirs his pseudo-western imagination with comparisons and equivalencies to his original symbolic repertoire. The narrative is predominantly organized by rhetori-

11 CALLADO, 1982, p. 25.

12 CALLADO, 1982, p. 50-52.

13 CALLADO, 1982, p. 29.

14 CALlADO, 1982, p. 38. 
cal irony. The emptying of the normative value of the two ethical systems of Callado's hero (the civilized morality and the Camaiurá mythology) functions as an antidote for what ailed Darcy Ribeiro's tragic hero, Isaías. In Maíra, the comparison of the church with the botequim would sound like a death sentence. Coming from Ipavu, in A Expedição Montaigne, it reaches the level of a parody. It is not the hybrid symbolism that kills the hero; it is tuberculosis that kills Ipavu, the last of the Native Brazilians, who ironically no longer truly wanted to be one.

Alternating the narrative focus between Ipavu (the expedition) and Ieropé (the tribe), the novel is able to construct ambivalent images of the indigenous culture. The "original" Native Brazilian is portrayed as the Pajé Ieropé, blind and humiliated by penicillin. Ieropé seems to bear, for Antonio Callado, a sentiment of religiousness, which, little by little, loses its meaning and is degraded. In an interview performed in April 1994, after confirming the presence of this religious motif in Quarup, the author added that

[A] Expedição Montaigne é a religião dos índios. O próprio pajé da história, de quem eu gosto muito, é um líder religioso. Ele está imbuído da idéia de Deus tanto quanto eu, ou muito mais do que eu. No entanto ele está numa posição de extrema inferioridade em relação aos meios em que tem de provar a sua força. A cura de doentes, inicialmente, estava ligada à magia, à capacidade que você tinha de curar. O pajé ainda tem esse aspecto perdido, de tratar os doentes com queima de ervas. O lado tocante do livro é isso: a inevitável desmoralização do pajé. ${ }^{15}$

Confronted with his humiliation, after allowing Maria Jaçanã to die by refusing her penicillin, Ieropé assumes the gravity of tragic characters; perhaps as does Isaias, challenged by the tension of the two worlds. The solution is a mixture of existential repression with zoomorphic fragmentation, which restores the confidence of the Pajé when he apparently frees himself of the responsibility of the death of Maria Jaçanã. Lígia Chiappini M. Leite points out suggestively that

[o] quixotesco sonho de Ieropé, como o de Beirão, é reverter o tempo, subir os rios ao contrário, por isso é trágico. Enquanto na tragédia antiga o destino ou os deuses arrastavam o herói 
para a desgraça, aqui é a História a força irresistível e irreversível que torna inúteis as tentativas. Só no delírio a História pode ser desfeita. Para continuar vivendo, o pajé inventa um outro elemesmo e um outro Fodestaine, contagiando a aldeia toda, progressivamente, com essa última ilusão. Mas o leitor fica de fora com a chave da mentira e a visão de Ipavu se afastando na canoa guiada pelo gavião rumo ao Morená, terceira margem. ${ }^{16}$

A Expedição Montaigne reflects on the impossibility of reversing time and on the rewriting of History. In the metaphors related to the flow of water (clearly a parody of Heraclitus) the narrative seems to be trying to convince itself (and the reader) of the irreversibility of time. The ironic pace that drives the novel discredits the historic utopias and the charms of myth. A Expedição Montaigne enacts many episodes whose tragic force is exhausted by the presence of parody, which converts tragedy into farce. The episode in the plaza of Pirapora, for example, which illustrates the primordial encounter of cultures, is ironically falsified by the behavior of civilized Native Brazilians who pretend to be savages in a kind of self-conscious imitation of the primitive. ${ }^{17}$ The final scene of the sacrifice of Beirão, symbolically converted by the Pajé Ieropé into Fodestaine, is also a double farce, as it ends up re-creating, in parody, two other historic bonfires: that of Saint Joan of Arc and that of Karl von den Steinen (i.e. the historical Fodestaine). This sacrifice has the effect of an ironic purgation, whose falsity of its ceremonial intentions can only be deciphered by the reader.

The death of the Expedition - the death of Beirão and of Ipavu - can be taken, therefore, as the impossibility of history and myth surviving in a world condemned to the production of parodies and farces of ancestral deeds. A Expedição Montaigne is meaningless when subject to models of prefiguration and redemption (as in Quarup) or taken through the perspective of mythical structures (as in Maira). In a world disenchanted by the insistent presence of satire, there is no place for Nando's projects of salvation, nor for the integrity of the norms of Isaías' two worlds. Ipavu lives in a universe where the most profound prayer could very well be the asking for a table at the bar. Beauty is not excluded from this world, nor is transcendence. But these moments are brief, dissolved in the whirlpool of a sublime anecdote that does not decide between the parodies of myth and of History.

In the 1960s, the concept of a natural path for History was available through the different models of Marxist "exegesis" of society. Padre Nando in Quarup figuratively stands for such pattern of intentionality, he embodies a very specific

16 LEITE, 1983, p. 230.

17 CALLADO, 1982, p. 40-43. 
and widely accepted way of reaching a political position and of making decisions accordingly. On the other hand, in the 1970s the expectation for the death of Darcy Ribeiro's Mairum community emerged as a fragmented and sublime discourse that challenged the destructive effects of the encounter of two cultures. Meanwhile, myth was still preserved by the dedicated desire of this author-anthropologist who demanded the need for the coexistence of parallel worlds, the world of history and that of myth. In the 1980s, however, history and myth were equally incomplete. Only stories remained, that showed at times through farce, at times through tragedy, the arbitrary nature of one of Brazil's recurrent patterns of literary representation of its national identity: the melancholic nativism. It is in that sense that the final scene of A Expedição Montaigne allows the reader one of the most inspiring images ever created by Brazilian fiction: the departure of Ipavu's body and of his hawk, Uiruçu, in a canoe set adrift, zoomorophically transformed into "uma escura serpente com topete de garça". ${ }^{18}$ It is not difficult for the reader to be carried off in trance by one of the rare moments of ecstasy that a world removed of History and myth can still conjure up while aiming at transcendence and heading - as in Guimarães Rosa's short story - for the third bank of the river.

\section{ABSTRACT}

Between the 1960s and the 1980s the image of the Native Brazilian was redefined in the context of the production of discourses and cultural practices associated with the construction of new symbols for Brazilian identity. In 1979 Walnice Nogueira Galvão pointed out that in the past the Native Brazilian never "had much luck" in the national cultural tradition, concluding that the publication of Maira, "shows how the Native Brazilian is more alive than ever in his connection with Brazilian literature". This essay presents a comparative interpretation of three contemporary novels - Quarup (1967) and A Expedição Montaigne (1982) by Antonio Callado (1917-1997), and Maíra (1976) by Darcy Ribeiro (1922-1997) - that relate direct or indirectly to the idea of Brazilian indigenous culture as a literary problematic source for identity. These works are discussed in the way they support or undermine specific ways of representing Brazilian nation. It focuses on how these novels use images and structures that either approximate or distance themselves from the repertoire of symbols associated with the

18 CALLADO, 1982, p. 129.

19 GALVĀO, 1979, p. 379-389. 
PASSOS, J. L. Nativism, Utopia, and Death...

indigenous cultural tradition, oscillating frequently between western visions of mythic themes and mythic visions of western themes.

Key words: Identity; nativism; $20^{\text {th }}$ century Brazilian novel.

\section{RESUMO}

Entre as décadas de 60 e 80 a imagem do índio foi reaquecida no contexto da produção de discursos e práticas culturais associadas à construção de novos símbolos para a nação brasileira. Em um ensaio de 1979, Walnice Nogueira Galvão apontou que o índio nunca "teve muita sorte" na tradição cultural nacional, para então concluir, a propósito da publicação de Maíra, "mostra[ndo] como o índio está mais vivo do que nunca em sua conexão com a literatura brasileira". Este ensaio realiza uma interpretação comparada de três obras que relacionam-se direta ou indiretamente com a cultura indígena ao nível temático e/ou estrutural. Assim, Quarup (1967) e A Expedição Montaigne (1982) de Antonio Callado (1917-1997), bem como Maira (1976) de Darcy Ribeiro (1922-1997), são acompanhados na maneira como suas narrativas constroem ou solapam determinados modos de falar sobre o nacional, utilizando imagens e estruturas que ora se aproximam e ora se distanciam do repertório de símbolos associados à tradição cultural indígena, oscilando freqüentemente entre visões ocidentais de temas míticos e visões míticas de temas ocidentais.

Palavras-chave: Identidade, indianismo, romance brasileiro do século XX.

\section{WORKS CITED}

AUERBACH, Erich. "Figura." In: Id. Scenes from the Drama of European Literature. Translated by Ralph Manheim. Minneapolis: University of Minnesota Press, 1959. p. 11-76.

BENSO, Silvia. "Uno Spazio Mitico All'Interno della Selva Brasiliana: La Comunitá Mairum." In: Studi di Letteratura Ispano-Americana 11 (1981), p. 99-105.

BOURDIEU, Pierre. The Field of Cultural Production. Ed. Randal Johnson. London: Polity Press, 1993.

CALLADO, Antonio. A Expedição Montaigne. $5^{\text {th }}$ ed. Rio de Janeiro: Nova Fronteira, 1982. Quanup. 12 $2^{\text {th }}$ ed. Rio de Janeiro: Nova Fronteira, 1984. . Interview with Cida Golin. “Antonio Callado: Um Mosaico dos Fragmentos da História

19 (GALVÃO, 1979, p. 379-389) 
Brasileira." In: Brasil/Brazil: Revista de Literatura Brasileira 13 (1995): 91-102.

GALVÃO, Walnice Nogueira. "Indianismo Revisitado." In: Esboço de Figura: Homenagem a Antonio Candido. São Paulo: Duas Cidades, 1979. p. 379-91

GONZALES, Christophe. Review of Maira by Darcy Ribeiro. In: Caravelle 38 (1982), p. 231-34.

LEITE, Lígia Chiappini Moraes. "Antonio Callado: Literatura e História." In: Escritura XIV.28 (1989), p. 487-94.

. "Quando a Pátria Viaja: Uma leitura dos romances de Antonio Callado." In: Id. $O$ Nacional e o Popular na Cultura Brasileira. São Paulo: Brasiliense, 1983. 130-234.

RIBEIRO, Darcy. Maíra. $2^{\text {nd }}$ ed. Rio de Janeiro: Civilização Brasileira, 1978. 